\title{
Pelatihan pengolahan ikan bandeng tanpa duri pada masyarakat pesisir di Desa Bulucindea Kabupaten Pangkep
}

\author{
Sri Udayana Tartar*, Zaimar, Sitti Nurmiah, Reta \\ Program Studi Agroindustri, Jurusan Teknologi Pengolahan Hasil Perikanan \\ Politeknik Pertanian Negeri Pangkajene Kepulauan \\ Email Korespondensi: "zaimarpolitani@ gmail.com
}

Received October 10, 2020 ; Revised May 8, 2021; Accepted June 30, 2021

\begin{abstract}
Abstrak
Ikan bandeng merupakan komoditas perikanan yang mempunyai cita rasa yang spesifik sehingga digemari banyak orang. Namun memiliki kekurangan yaitu mempunyai tulang dan duri yang banyak. Salah satu cara sederhana untuk mengatasi kekurangan tersebut adalah dengan diversifikasi olahan dalam bentuk ikan bandeng tanpa duri. Olehnya itu tujuan kegiatan pengabdian masyarakat ini adalah memberdayakan kelompok masyarakat melalui pelatihan pengolahan bandeng tanpa duri. Adapun kelompok masyarakat tersebut berlokasi di kawasan pesisir di Desa Bulu Cindea Pangkep. Metode yang diterapkan adalah (i) penyuluhan, (ii) demonstrasi berupa praktek langsung. Sedangkan evaluasi prospek pengembangan usaha menggunakan analisis SWOT. Hasil kegiatan pelatihan menunjukkan bahwa metode penyuluhan dan demonstrasi dapat menerapkan teknologi sederhana kepada masyarakat. Hasil praktik pencabutan duri diperoleh bahwa rata-rata masih membutuhkan waktu lebih dari 15 menit per ekor berarti masih dibawah standar yang terampil. Hasil analisis SWOT untuk prospek pengembangan usaha lebih lanjut diperlukan strategi peningkatan keterampilan teknis pelaku usaha, perangkat teknologi peralatan dan sarana yang memadai, pemasaran melalui promosi dan kerjasama dengan mitra usaha atau industri.
\end{abstract}

Kata Kunci: ikan bandeng; bandeng tanpa duri; pemberdayaan; masyarakat pesisir

Milkfish is a fishery commodity that has a specific taste that is favored by many people. But it has a disadvantage, namely having a lot of thorns and spines. One simple method to overcome this shortage is by diversifying its processing in the form of thornless milkfish. Therefore, the purpose of this community service activity is to empower community groups through thornless milkfish processing training. The community group is located in a coastal area in Bulu Cindea Village, Pangkep. The methods that applied are (i) counseling, (ii) demonstration in the form of direct practice. Meanwhile, the evaluation of business development prospects uses a SWOT analysis. The results of the training activities showed that counseling and demonstration methods could apply simple technology to the community. The results of the practice of removing thorns showed that on average it still took more than 15 minutes per head, meaning that it was still below the skilled standard. The results of the SWOT analysis for the prospect of further business development required strategies of improvement in the technical skills of business actors, adequate technology equipment and facilities, marketing through promotion and cooperation with business or industrial partners.

Keywords: milkfish; thornless milkfish; empower; coastal community

\section{PENDAHULUAN}

Diversifikasi produk hasil perikanan diharapkan dapat meningkatkan pendayagunaan dan usaha pengolahan hasil perikanan untuk diolah menjadi produk pangan yang bergizi tinggi, enak, murah, dan mudah didapat. Salah satu produk perikanan adalah ikan bandeng. Diversifikasi produk olahan bandeng merupakan upaya untuk mencukupi selera masyarakat dalam mengkonsumsi ikan sebagai sumber protein. Dengan demikian, pengembangan produk bandeng akan mendorong minat petambak untuk melakukan peningkatan produksi dan tentunya akan mendorong peningkatan olahan ikan bandeng [1]. Salah satu olahan ikan bandeng adalah bandeng tanpa duri. Produk ini menambah keanekaragaman produk dalam memenuhi tuntutan selera konsumen.

Provinsi Sulawesi Selatan memiliki potensi kelautan dan perikanan yang cukup tinggi dan memiliki keragaman jenis ikannya. Salah satu komoditi perikanan adalah ikan bandeng merupakan yang tertinggi di Indonesia dengan produksi sebesar 127.434,1 ton [2], atau setara dengan 18,9 persen dari produksi nasional. Kabupaten Pangkep sebagai penghasil ikan bandeng sebesar 28.759 ton dengan produksinya meningkat dari tahun ke tahun nilai yang cukup tajam dengan kenaikan 13,9 persen [3]. 
Ikan bandeng, merupakan jenis ikan yang mempunyai cita rasa yang spesifik, digemari banyak orang dan dikenal luas oleh masyarakat baik domestik maupun international. Selain itu, ikan bandeng memiliki kandungan protein yang tinggi sebesar 20,38\% merupakan salah satu sumber pangan yang sangat bergizi. Namun juga memiliki kekurangan yaitu mempunyai tulang dan duri yang banyak sehingga masyarakat kurang menyukai [4]. Jumlah duri pada ikan bandeng terdapat pada bagian punggung ada 42 pasang duri bercabang yang menempel di dalam daging dekat permukaan kulit luar, bagian tengah ada 12 pasang duri pendek, pada rongga perut ada 16 duri, dan bagian perut dekat ekor ada 12 pasang duri kecil [5].

Salah satu teknologi sederhana untuk mengatasi kekurangan dari bahan baku ikan bandeng adalah penanganan/pengolahan ikan bandeng tanpa duri. Dengan cara ini tidak memiliki risiko hilangnya kandungan gizi yang terdapat pada bandeng tersebut. Dengan penerapan rantai dingin dan variasi dalam penyajiannya dapat lebih mudah diolah menjadi berbagai jenis makanan [6]. Selain itu produk bandeng tanpa duri dapat memudahkan pengolahan ikan lebih lanjut. Sesuai dengan harga dasar ikan bandeng segar di pasaran di kota Makassar seharga Rp. 20.000 per kg maka setelah dicabut durinya harganya menjadi Rp. 50.000 per kg. Dengan adanya selisih keuntungan dari pengolahan tersebut maka berpeluang untuk menjadi usaha atau bisnis di masyarakat, terutama untuk daerah pesisir dengan areal tambak ikan bandeng di Desa Bulu Cindea Kabupaten Pangkep. Adapun beberapa potensi perikanan yang dapat menunjang usaha bisnis di bidang perikanan di daerah tersebut dapat dilihat pada tabel 1.

Tabel 1. Potensi Desa Bulu Cindea Pangkep [7]

\begin{tabular}{ll}
\hline \multicolumn{1}{c}{ Uraian } & \multicolumn{1}{c}{ Data Potensi } \\
\hline Luas geografis & $7,00 \mathrm{~km}$ persegi \\
Jarak dari ibukota kecamatan \& kabupat & $6 \mathrm{~km}$ dan $7,4 \mathrm{~km}$ \\
Luas areal tambak & $375,68 \mathrm{Ha}$ \\
Produksi ikan bandeng & $2.178,94$ ton \\
Jumlah penduduk & 4.605 orang \\
Jumlah penduduk usaha bidang perikanar & 936 orang \\
Tempat pelelangan ikan (TPI) & 1 buah \\
Tempat wisata pantai & 3 buah \\
Jumlah unit koperasi & 4 buah \\
Jumlah anggota koperasi & 1.171 orang \\
\hline
\end{tabular}

Untuk mengantisipasi kondisi tersebut di atas maka diperlukan penerapan teknologi pengolahan ikan bandeng melalui pembimbingan yang berorientasi pada kegiatan diversifikasi olahan ikan bandeng tanpa duri yang diharapkan dapat meningkatkan nilai tambah produk. Olehnya itu tujuan kegiatan pengabdian masyarakat ini adalah memberdayakan kelompok masyarakat melalui pelatihan penanganan/pengolahan bandeng tanpa duri.

\section{METODE}

Secara garis besar metode pelaksanaan yang diterapkan pada kelompok masyarakat sasaran adalah sebagai berikut:

a. Penyuluhan

o Penyuluhan tentang penanganan bahan baku ikan melalui penerapan rantai dingin untuk menjamin mutu kesegaran ikan.

o Penyuluhan tentang cara pengolahan yang memenuhi standar mutu ikan bandeng tanpa duri sesuai standar SNI.

b. Demonstrasi

o Praktek penanganan bahan baku dan cara pengolahan bandeng tanpa duri.

o Praktek tentang cara teknis penggunaan alat yang aman dan tetap menjaga kesegaran mutu ikan.

Adapun kelompok sasaran dan tempat pelaksanaan pengabdian pada masyarakat adalah kelompok masyarakat keluarga petani tambak di kelurahan Bulu Cindea Kecamatan Bungoro Kabupaten Pangkep Sulawesi Selatan dengan melibatkan 17 orang peserta pelatihan. Untuk memberikan gambaran tentang prospek dan kendala akan yang dihadapi masyarakat dalam mengembangkan produk bandeng tanpa duri di Desa Bulu Cindea maka dilakukan metode analisis SWOT.

\section{HASIL DAN PEMBAHASAN}

a. Sosialisasi dan Penyuluhan

Hasil sosialisasi dan penyuluhan pada kelompok masyarakat pesisir Dusun Biringkassi di Desa Bulu Cindea Pangkep dengan peserta ibu rumah tangga dan remaja puteri dari kelompok karang taruna dan sadar wisata sangat antusias dalam mengikuti kegiatan tersebut. Meskipun dalam kondisi pandemic Covid-19 yang mengharuskan pemakaian masker bagi peserta dan pelatih serta tetap menjaga jarak antar peserta. Meskipun 
Kabupaten Pangkep tergolong zona Hijau, namun Tim Pengabdian berasal dari Kotamadya Makassar yang masih zona orange jadi tetap mematuhi dan menjalankan protokol kesehatan.

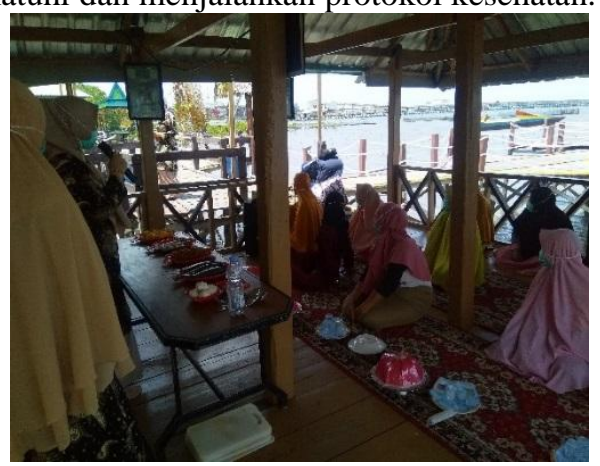

Gambar 1. Lokasi pelatihan di Baruga pesisir Bulu Cindea Pangkep

Penyuluhan diberikan pada kelompok masyarakat untuk meningkatkan pengetahuan dan menyamakan persepsi tentang bagaimana menangani atau mengolah ikan bandeng tanpa duri secara tepat sesuai dengan standar mutu. Adapun materi penyuluhan berupa penanganan bahan baku dengan penerapan metode rantai dingin dan pengolahan ikan bandeng tanpa duri. Teknik penyuluhan dengan metode ceramah dan umpan balik dari peserta pelatihan selama kegiatan pelatihan merupakan cara yang akurat untuk memberikan pemahaman yang lebih cepat dan tepat.

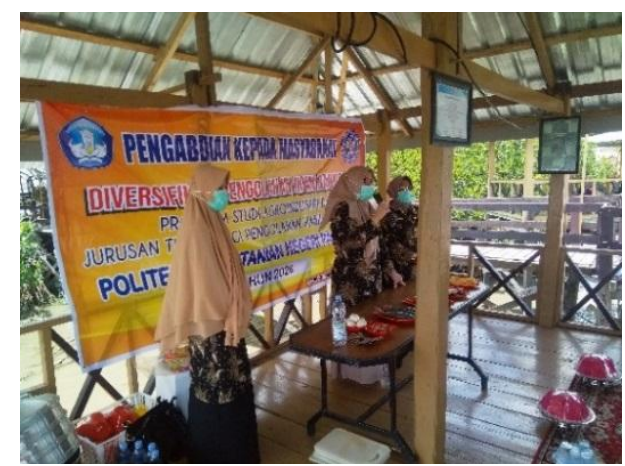

Gambar 2. Penyuluhan materi penanganan bahan baku ikan bandeng

\section{b. Penanganan Bahan Baku}

Penanganan baku merupakan aspek penting dalam pengolahan ikan karena ikan termasuk bahan yang mudah rusak atau busuk kalau tidak ditangani dengan benar dan tepat. Dengan penanganan yang tepat menjamin mutu kesegaran ikan melalui penerapan rantai dingin pada setiap tahapan penanganan/pengolahan bahan baku. Rantai dingin adalah penerapan suhu dingin setiap kegiatan untuk mempertahankan suhu dingin mulai dari penerimaan bahan baku, distribusi hingga sampai ke konsumen [8], Menurut [9] penangananan ikan bandeng harus segera dilakukan dengan dicuci dan ditambahkan es untuh mendekati suhu $0^{\circ} \mathrm{C}$ sebagai penerapan rantai dingin (cold chain) yang dapat menghambat pertumbuhan mikroba sebagai penyebab kemunduran mutu ikan.

Adapun proses penangangan yang tepat [4] dan [10] dengan tahapan berikut:

- Ikan dicuci dengan menggunakan air yang mengalir agar kotoran yang melekat pada permukaan kulit dapat terikut bersamaan dengan aliran air dan mengurangi jumlah mikroorganisme;

- Ikan bandeng dibelah pada bagian punggung berbentuk seperti kupu-kupu dari mulai kepala sampai pada pangkal ekor, diusahakan pengirisan tidak memotong tulang punggung;

- Ikan bandeng dibersihkan dengan cara membuang isi perut, kotoran, dan insang;

- Ikan bandeng dicuci kedua kali agar bandeng bersih dari sisa-sisa darah. Terdapat tiga pusat konsentrasi bakteri pada ikan, yaitu pada isi perut, insang, dan kulit. Teknik yang paling baik adalah dengan cara menyemprot ikan terutama bagian dalam ikan.

Selain metode penyuluhan yang diberikan maka dilakukan metode demonstrasi atau praktek langsung yang diawali oleh anggota tim pengabdian yang telah mahir atau kompeten dalam melakukan kegiatan penanganan hingga pencabutan duri ikan bandeng. Kompetensi yang dimaksud disini adalah kemampuan untuk melakukan tahapan pekerjaan dengan tepat dan waktu standar atau seminimal mungkin.

Dengan adanya contoh atau metode yang diberikan ke peserta pelatihan yang diamati langsung dan sambil bertanya tentang apa yang belum dipahami. Selanjutnya satu persatu peserta pelatihan mempraktikkan sendiri setiap tahapan kegiatan yang dipandu oleh anggota tim pengabdian. 


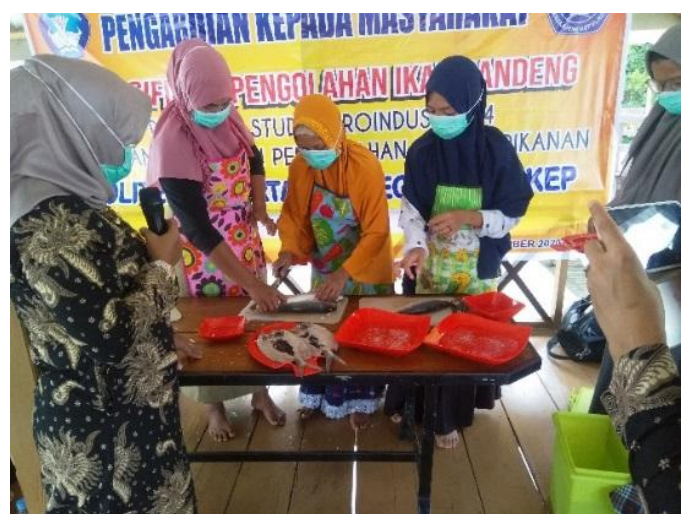

Gambar 3. Praktik langsung oleh peserta dipandu oleh anggota Tim Pengabdian

Hasil praktik seluruh peserta pelatihan memberikan gambaran bahwa setiap tahapan pengolahan masih perlu dilakukan pengulangan karena sebagian besar peserta adalah pemula. Dan ada peserta yang sudah mahir karena telah mendapatkan pelatihan sebelumnya. Hal ini menunjukkan bahwa setiap keterampilan membutuhkan jam praktik yang lebih banyak untuk mendapatkan hasil yang maksimal.

\section{c. Pencabutan Duri Ikan Bandeng}

Pencabutan duri ikan bandeng adalah tahapan pengolahan yang membutuhkan keterampilan dan kesabaran yang tinggi untuk mendapatkan mutu ikan bandeng tanpa duri yang baik. Disamping itu juga faktor kesegaran ikan dan penanganan yang tepat sangat mempengaruhi mutunya. Pencabutan duri masih menggunakan cara sederhana atau manual dengan memakai peralatan seperti pinset, pisau dan gunting ikan, talenan [11]. Peralatan ini harus tajam dan pinset harus rapat bergerigi. Disamping itu harus steril dan terbuat dari bahan anti karat (steinless steel). Adapun tahapan atau prosedur pencabutan duri ikan bandeng [4] adalah sebagai berikut:

- Pencabutan duri bandeng dilakukan secara berurutan sesuai tahapan dengan metode rantai dingin dimana ikan bandeng yang akan dikeluarkan tulang dan durinya dicabut diatas keranjang yang di bawahnya diisi dengan es curah.

- Kemudian pencabutan dimulai dari bagian yang dianggap paling mudah sampai ke bagian yang dirasa paling sulit.

- Pencabutan dimulai dengan membuang tulang punggung/tulang belakang ditarik dari bagian ekor hingga kepala, daging ikan ditekan agar tidak ikut tertarik keatas sampai ke bagian kepala.

- Selanjutnya dilakukan pencabutan duri di daerah dada dekat kepala (jumlah duri 12 pasang), duri bagian perut sebanyak 16 duri, duri punggung berjumlah 42 duri bercabang yang berada dalam daging ikan dekat kulit luar di sisi kiri dan 42 duri di sisi kanan.

- Pencabutan duri selanjutnya pada bagian depan dekat penutup insang, duri di dekat pangkal ekor jumlah duri 12 pasang.

- Pemotongan sirip punggung diawali dari pangkal punggung hingga sirip terlepas.

- Perabaan dilakukan untuk memastikan duri telah tercabut semua. Setelah duri tercabut semua ikan bandeng tanpa duri siap dikemas.

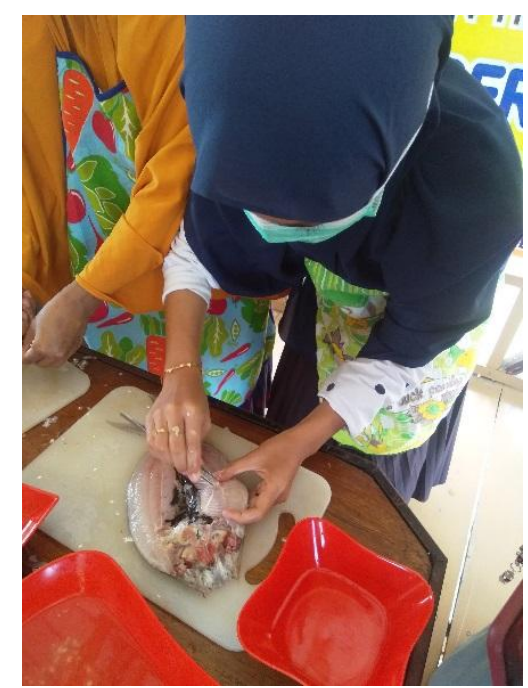

Gambar 4. Pencabutan duri ikan oleh salah satu peserta pelatihan 
Untuk mendapatkan mutu ikan tanpa duri yang baik adalah harus memenuhi persyaratan:

- Ikan masih dalam kondisi segar

- Tidak terdapat lagi duri ikan baik dari yang besar sampai yang halus.

- Semua bagian daging ikan masih utuh dan tidak ada yang hilang.

- Struktur atau tekstur daging ikan masih dalam kondisi kompak.

- Ikan dalam kondisi steril atau bebas dari bahan kontaminan.

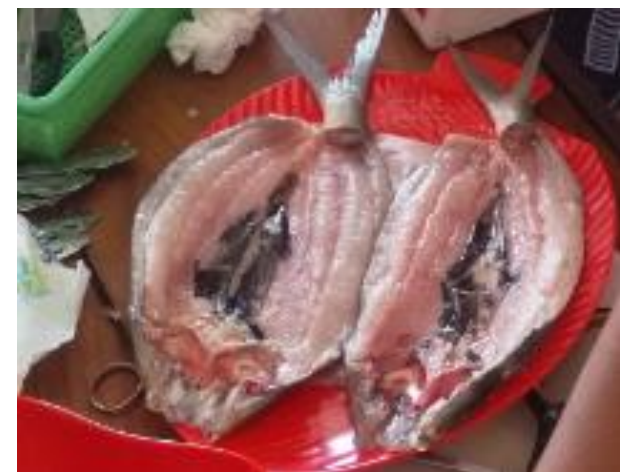

Gambar 5. Ikan bandeng tanpa duri yang telah terseleksi baik

Tabel 2. Analisis SWOT prospek pengembangan ikan bandeng tanpa duri.

\begin{tabular}{|c|c|}
\hline Kekuatan (Strength) & Kelemahan (Weakness) \\
\hline $\begin{array}{l}\text { Sumberdaya tambak dan pesisir yang cu } \\
\text { memadai. } \\
\text { Bahan baku ikan segar diperoleh dari tam } \\
\text { wilayah sendiri jadi kesegaran ikan terjamin. } \\
\text { Dukungan sarana berupa TPI sebanyak } 1 \text { ini } \\
\text { unit koperasi dan daerah wisata pesisir. } \\
\text { Besarnya dukungan masyarakat dan pemerir } \\
\text { setempat dalam pengembangan ikan band } \\
\text { sebagai komoditas unggulan daerah. } \\
\text { Kemudahan dalam pemasaran dan distril } \\
\text { karena jarak ke ibukota kabupaten relatif df } \\
\text { dan kondisi jalan yang cukup memadai (bera: } \\
\text { beton). }\end{array}$ & $\begin{array}{l}\text { Pengetahuan dan keterampilan masyari } \\
\text { mengenai pengolahan ikan berstandar mutu mi } \\
\text { minim. } \\
\text { Belum ada industri yang mengolah langsung } \mathrm{h} \\
\text { tangkapan nelayan di tambak atau di pera } \\
\text { menjadi produk perikanan jadi sebagian br } \\
\text { dijual dalam bentuk segar. } \\
\text { Belum ada kerjasama antara unit usaha den } \\
\text { industri berskala menengah ke atas. } \\
\text { Peralatan pascapanen hasil perikanan tam } \\
\text { masih minim sehingga sebagian besar manual. } \\
\text { Belum tersedia cold storage untuk penyimpa } \\
\text { ikan bandeng segar skala besar. }\end{array}$ \\
\hline
\end{tabular}

Peluang (Opportunities)

Ikan bandeng sebagai komoditas unggulan dat Adanya produk sejenis dari luar yang $\mathrm{m}$ Kabupaten Pangkep.

Adanya permintaan produk bandeng tanpa duri , menarik.

wilayah luar kabupaten.

Larangan ekspor bagi perusahaan pengolah i

Rasa dan aroma khas yang spesifik ikan bandeng, yang tidak memiliki tenaga bersertifikat Star

Pangkep yang banyak digemari konsumen di pasc Pengolahan ikan (SPI) dan belum menerap domestik.

Nilai tambah berupa peningkatan nilai jual 2 kali 1

dari hasil pengolahan ikan bandeng tanpa duri. standar mutu manajemen CPPOB dan HACCP.

Hasil kegiatan praktik pencabutan duri oleh peserta pelatihan diperoleh bahwa rata-rata masih membutuhkan waktu lebih dari 15 menit per ekor. Sementara standar untuk yang terampil hanya berkisar 7-10 menit per ekor. Dengan hasil ini dibutuhkan pelatihan yang intensif bagi masyarakat yang akan menggeluti usaha bisnis bandeng tanpa duri agar dapat lebih terampil. Dan selanjutnya diharapkan dapat memilki sertifikat kompetensi sebagai persyaratan untuk pendirian usaha yang lebih besar yang berstandarisasi dan untuk pengembangan lebih lanjut.

\section{d. Evaluasi Pengembangan}

Analisis SWOT digunakan untuk mengevaluasi secara keseluruhan dari aspek kekuatan (Strength), kelemahan (Weakness), peluang-peluang (Opportunities), dan ancaman (Threats) yang dapat merupakan 
instrumen lingkungan internal dan eksternal [12]. Berdasarkan analisis SWOT untuk prospek pengembangan usaha bidang pengolahan ikan bandeng tanpa puri di Desa Bulu Cindea Pangkep dapat dilihat pada tabel 2.

Hasil analisis SWOT pada tabel 2 maka dapat diperoleh strategi-strategi alternatif pengembangan usaha pengolahan ikan bandeng tanpa duri adalah sebagai berikut:

Stratregi Opportunities $(O)$ - Strength $(S)$

- Pemanfaatan optimal sumberdaya tambak untuk diolah menjadi produk nilai tambah dari nilai jual produk olahan ikan bandeng.

- Diperlukan promosi dalam pengenalan produk yang intensif untuk peningkatan pemasaran lokal dan nasional.

- Diperlukan upaya mempertahankan mutu bahan segar ikan bandeng rasa spesifik dengan pemanfaatan teknologi budidaya dan penanganan/pengolahan ramah lingkungan.

- Pemanfaatan sarana prasarana perikanan yang maksimal dalam mendukung kegiatan pengolahan hasil perikanan dan pemasaran produk.

Strategi Opportunities $(O)$ - Weakness (W)

- Diperlukan pelatihan yang intensif bagi masyarakat pelaku usaha dalam rangka peningkatan mutu produk ikan bandeng tanpa duri.

- Pemanfaatan dukungan pemerintah dan masyarakat setempat untuk pendirian usaha pengolahan ikan bandeng berstandar mutu yang dilengkapi dengan peralatan pengolahan dan sarana penyimpanan cold storage yang memadai.

- Dibutuhkan mitra kerjasama dengan usaha atau industri dari luar wilayah untuk pemasaran produk dalam jumlah besar.

Strategi Threats $(T)$ - Strength $(S)$

- Pemanfaatan teknologi penanganan rantai dingin yang optimal dan teknologi kemasan untuk mempertahankan kesegaran ikan bahan baku dan mutu olahan ikan bandeng.

- Diperlukan dukungan pemerintah dan masyarakat yang lebih intens dalam mempromosikan produk ikan bandeng asal Pangkep.

Strategi Threats $(T)$ - Weakness $(W)$

○ Diperlukan peningkatan keterampilan atau kompetensi anggota masyarakat sebagai pelaku usaha untuk mendapatkan Sertifikat Pengolah Ikan (SPI) dan CPPOB/ HACCP.

- Diperlukan teknologi peralatan pendukung untuk menghasilkan produk olahan ikan bandeng bermutu tinggi.

Dengan adanya strategi-strategi pengembangan di atas maka dapat dijadikan acuan atau kebijakankebijakan yang strategis sebagai masukan bagi pemerintah daerah dan pengusaha dalam rangka mendirikan atau mengembangkan usaha bandeng tanpa duri yang lebih besar ke depan pada masyarakat pesisir di Desa Bulu Cindea Kabupaten Pangkep.

\section{KESIMPULAN}

Hasil sosialisasi dan penyuluhan pada kelompok masyarakat pesisir di Desa Bulu Cindea yang hadir pada saat kegiatan pengabdian masyarakat sangat antusias dalam mengikuti kegiatan tersebut. Meskipun dalam kondisi pandemic Covid-19. Dengan metode penyuluhan dan demonstrasi langsung dapat menerapkan teknologi sederhana pada masyarakat, meskipun yang dihasilkan yang dipraktikkan peserta pelatihan masih perlu perbaikan dan pengulangan. Hasil kegiatan praktik pencabutan duri oleh peserta pelatihan diperoleh bahwa rata-rata masih membutuhkan waktu lebih dari 15 menit per ekor berarti masih dibawah standar dari yang terampil.

Hasil analisis SWOT secara keseluruhan untuk pengembangan usaha ikan bandeng tanpa duri adalah dibutuhkan strategi-strategi peningkatan keterampilan/kompetensi pelaku usaha, peningkatan perangkat teknologi peralatan dan sarana yang memadai untuk menghasilkan produk bermutu tinggi serta pengembangan pemasaran melalui promosi produk yang lebih intensif dan kerjasama dengan mitra usaha/industri.

\section{UCAPAN TERIMA KASIH}

Ucapan terima kasih kepada lembaga P3M Politeknik Pertanian Negeri Pangkajene Kepulauan yang telah memberi dukungan pada kegiatan pengabdian ini. Begitupula kepada pemerintah setempat dan pemuka masyarakat Desa Bulu Cindea Pangkep telah menfasilitas tempat berlangsungnya kegiatan pengabdian ini.

\section{DAFTAR PUSTAKA}

[1] T. Achmad, A. Triono, T. Aslianti, T. Setiadarma, dan Kasprio, "Pedoman Teknis Pembenihan Ikan Bandeng" Seri Perkembangan Hasil Penelitian Perikanan. Jakarta; Badan Litbang Pertanian, 1993.

[2] BPS, "Sulawesi Selatan dalam Angka". Biro Pusat Statistik Sulawesi Selatan, Makassar. 2018.

[3] Direktorat Jenderal PK2P, "Statistik Perikanan Indonesia". Jakarta; Departemen Kelautan dan Perikanan, 2003.

[4] B. Vatria, "Pengolahan Ikan Bandeng (Chanos chanos Forsk) Tanpa Duri". Jurnal Ilmu Pengetahuan dan Rekayasa, pp. $18-23,2010$.

[5] BPPMHP, "Ikan bandeng dan Produk Diversifikasinya". Jakarta (ID): Departemen Kelautan dan Perikanan, 2004. 
[6] C. Saparinto, "Bandeng Tanpa Duri dan Cara Pengolahannya". Semarang (ID): Dahara Prize, 2009.

[7] BPS, "Pangkep dalam Angka". Biro Pusat Statistik Kabupaten Pangkep, Makassar. 2018.

[8] T. M. Simatupang, "Struktur dan Sistem Rantai Pendingin Ikan dalam Rangka Pengembangan Sistem Logistik Ikan Nasional (SLIN)", 2016. https://supplychainindonesia.com/sistemrantai-dingin-cold-chain-dalamimplementasi-sistem-logistik-ikan-nasional-slin.html.

[9] E. Afrianto dan E. Liviawaty, "Pengawetan dan Pengolahan Ikan". Yayasan Kanisius, Jogyakarta, 2011.

[10] S. Ilyas dan Abdurrahman, "Perbaikan Handling dan Distribusi Ikan Basah". Laporan Penelitian Lembaga Teknologi Pertanian No. 2, Jakarta, 1971.

[11] E. Nusantari, A. Abdul, R. Marsuci, Harmain, "Ikan Bandeng Tanpa Duri (Chanos chanos) sebagai Peluang Bisnis Masyarakat Desa Mootinelo, Kabupaten Gorontalo Utara, Provinsi Gorontalo”. Agrokreatif, Vol 3 (1): 78-87, 2016.

[12] P. Kotler dan K. L. Keller, "Manajemen Pemasaran". Alih Bahasa oleh Ali Rangkuti, Freddy. Penerbit Erlangga, Jakarta, 2014. 
